\title{
THE ROLE OF HELICOBACTER PYLORI IN PATHOGENESIS
}

\section{OF HYPEREMESIS GRAVIDARUM}

\author{
MAYSOON SHARIEF ${ }^{1}$, NAWALHADI AL-ABASSY ${ }^{2} \&$ SURAZAEYAN GAR-ALLAH $^{3}$ \\ ${ }^{1}$ Department of Gynecology \& Obstetrics, College of Medicine, University of Basrah, Basrah, Iraq \\ ${ }^{2,3}$ Maternity and Child Hospital, Ashar, Basrah, Iraq
}

\section{ABSTRACT}

OBJECTIVE

To evaluate the role of Helicobacter pylori in the pathogenesis of HG and the value of adding a non-teratogenic regimen for its treatment in intractable cases.

\section{PATIENTS \& METHODS}

Sixty pregnant women with hyperemesis gravidarum $(\mathrm{HG})$ were matched with 60 control pregnant women with no history of HG. The study was conducted at Basrah Maternity and Child Hospital. A full history was obtained including medical disorder and drug usage. Serum H.pylorilgG antibody titres were estimated by using commercial ELIZA method for all patients and control. The pregnant women with positive H.pylori test were subdivided into 2 groups for the purpose of treatment. The first group was received traditional treatment of HG which include I/V fluid, antiemetic, antacid and vitamin supplement. The second group was received H.pylori treatment include proton pump inhibitor, amoxicillin and metronidazole. Then, both groups were followed up for the number of vomiting, duration of hospitalization and pregnancy outcome.

\section{RESULTS}

Fifty three out of 60 women with HG were seropositive for H.pylori(85\%) and 34 out of 60 control group were seropositive (55\%). It is highly significant in regard to primigravida and level of education between the seropositive and seronegative in the studied group. There is significant clinical improvement in patients who received H.pylori regimen than the group who received traditional therapy regard duration of admission to hospital and decrease number and frequency of vomiting in the studied group.

\section{CONCLUSIONS}

Helicobacter pylori should be considered as one of the causes of HG and screening for it should be added for investigation. H.pyloriregimen may be considered in intractable cases.

KEYWORDS: Helicobacter pylori, Hyperemesis, Pathogenesis \& Pregnancy

Received: May 07, 2018; Accepted: May 28, 2018; Published: Jul 07, 2018; Paper Id.: IJMPSAUG20181

\section{INTRODUCTION}

Hyperemesis gravidarum (HG) is a condition of intractable vomiting during pregnancy, leading to fluid, electrolyte and acid-base imbalance, nutrition deficiency and weight loss often severe enough to require hospital admission. It occurs between $4^{\text {th }}$ and $10^{\text {th }}$ week of gestation and it resolute by 20 week of gestation ${ }^{(1)}$. Symptoms will persist among $10 \%$ of patients throughout pregnancy ${ }^{(2)}$. 
There are numerus theories regarding the cause of HG including hormonal, placental serum marker, immunology and Helicobacter pylori infection ${ }^{(3)}$. An increased incidence of H.pylori infection has been observed in gastric antrum and corpus in HG patients. A small portion of H.pylori infected subjects develop peptic ulcers and gastric carcinoma, usually during adulthood ${ }^{(4)}$.

Adhesion, such as outer inflammatory protein binding adhesion, facilitate bacterial attachments to host epithelium leading to inflammatory response ${ }^{(5,6)}$.

The aim of the study is to evaluate the role of H.pyloriin the pathogenesis of HG and the value of adding a nonteratogenic regimen for its treatment in intractable cases.

Patients and Methods

This is a prospective case control study which was conducted at Basrah Maternity and Child Hospital during the period from May 2014 till October 2015. Sixty pregnant women with a history of hyperemesis gravidarum were enrolled in the study. The criteria for diagnosis of HG included severe vomiting (more than 3 times/day) which interfere with ordinary life of the patient and need admission to the hospital with or without ketonuria. Exclusion was done for women with hyperthyroidism, psychological disorders, hepatic disorders, urinary tract infection or intra cranial disorders.

The control group involved 60 pregnant women without HG, matched for age, parity and gestational age. Serum H.pyloriIgG antibody titre was estimated by using commercial ELISA method for all patients and control group. The pregnant women with positive IgG test were subdivided into 2 groups for the purpose of treatment.

The first group was received traditional treatment for $\mathrm{HG}$ which include $\mathrm{I} / \mathrm{V}$ fluid and antiemetic drug (metoclopramide 5-10mg/day, antacid and vitamin supplement). The second group was received H.pyloritreatment according to guideline recommendation which included triple therapy: proton pump inhibitor omerprazole 20mg/2days, amoxicillin $2 \mathrm{~g}$ /days, metronidazole $500 \mathrm{mg} / 2$ times daily rectally or $\mathrm{I} / \mathrm{V}$ for 5 days.

Statistical analysis: X2 test was used for nominal values and paired t-test by using SPSS. Value $<0.05$ considered statistically significant.

\section{RESULTS}

The demographic data of both groups were summarized in Table (1). There were no statistical differences between the patients and control groups in terms of age, gestational period and parity. Positive serum H.pyloriIgG antibody was detected in 53 out of 60 pregnant women with HG (85\%) in comparison to 34 out of 60 control women (55\%) with P value $<0.05$ (Table 2). Among patients group, the seropositive was not significantly different from the seronegative in relation to age, multiparity, gestational age at time symptoms onset, duration of symptoms and rate of abortion (Table 3). Never the less, there was high significant relationship in regard to primigravidae and education level which was significantly high in seropositive patients than in seronegative patients (Table 3). No significant difference was observed between the patients and control group in regard to number need admission to the hospital and severity of vomiting (Table 4). But there was significant difference in relation to duration of staying in the hospital and dehydration status.

As far as treatment is concerned, there was clear observation for patients with H.pylori regime in regard to staying in the hospital, dehydration status, improvement in the frequency of vomiting which was statistically significant (Table 5). 
Table 1: Characteristic Features of Patients and Control Groups

\begin{tabular}{|l|c|c|l|}
\hline \multicolumn{1}{|c|}{ Variable } & $\begin{array}{c}\text { Hyperemesis Gravidarum } \\
\mathbf{N = 6 0}\end{array}$ & $\begin{array}{c}\text { Control } \\
\mathbf{N = 6 0}\end{array}$ & \multicolumn{1}{|c|}{ P Value } \\
\hline Age (years) & $25 \pm 3.6$ & $24 \pm 3.3$ & N/S \\
\hline Primigravida & $53(88.3 \%)$ & $55(91.7 \%)$ & N/S \\
\hline Multigravida & $7(11.7 \%)$ & $5(8.3 \%)$ & N/S \\
\hline $\begin{array}{l}\text { Gestational weeks at time of } \\
\text { blood sample. }\end{array}$ & $9.2 \pm 1.2$ & $10 \pm 1.6$ & N/S \\
\hline
\end{tabular}

Table 2: Seropositivity of H.Pyloriin Patients and Control Groups

\begin{tabular}{|l|c|c|c|}
\hline Group & Patients with HG & Control & P Value \\
\hline Positive & $53(85 \%)$ & $34(55 \%)$ & 0.05 \\
\hline Negative & $7(15 \%)$ & $26(45 \%)$ & 0.05 \\
\hline Total & $60(100 \%)$ & $60(100 \%)$ & \\
\hline
\end{tabular}

Table 3: Characteristics of Patients in Regard to H.Pyloriseropositive.

\begin{tabular}{|l|c|c|c|}
\hline & $\begin{array}{c}\text { Seropositive } \\
\mathbf{N = 5 3}\end{array}$ & $\begin{array}{c}\text { Seronegative } \\
\mathbf{N = 7}\end{array}$ & P Value \\
\hline Age (years)* & $26+3.0$ & $24+4.0$ & N/S \\
\hline Primigravida & $46(86.8 \%)$ & $7(85.7 \%)$ & 0.001 \\
\hline Multigravida & $6(13.2 \%)$ & $1(14.3 \%)$ & N/S \\
\hline $\begin{array}{l}\text { Education } \\
\text { Primary school }\end{array}$ & $15(28.3 \%)$ & $2(28.6 \%)$ & 0.05 \\
Higher school & $38(71.7 \%)$ & $5(71.4 \%)$ & 0.05 \\
\hline $\begin{array}{l}\text { Symptoms onset } \\
\text { (Gestational week) }\end{array}$ & $7.66 \pm 0.7$ & $7.37 \pm 0.8$ & N/S \\
\hline $\begin{array}{l}\text { Symptoms duration } \\
(\text { weeks) }\end{array}$ & $9.52 \pm 1.2$ & $8.63 \pm 1.6$ & N/S \\
\hline Abortion & $3(6.3 \%)$ & $1(14.3 \%)$ & N/S \\
\hline *= mean + S.D & & &
\end{tabular}

Table 4: The Response to Traditional Treatment Measure in Sero positive Group to HG

\begin{tabular}{|l|c|c|c|}
\hline \multicolumn{1}{|c|}{ Criteria } & $\begin{array}{c}\text { Seropositive } \\
\mathbf{N = 5 3}\end{array}$ & $\begin{array}{c}\text { Seronegative } \\
\mathbf{N = 7}\end{array}$ & P value \\
\hline Admission to hospital & $34(64 \%)$ & $3(42 \%)$ & 0.05 \\
\hline Duration of staying hospital & $3-5$ days & $2-3$ days & 0.05 \\
\hline $\begin{array}{l}\text { Ketonuria } \\
\text { Positive }\end{array}$ & $29(54.7 \%)$ & $\begin{array}{l}1(14.3 \%) \\
6(85.7 \%)\end{array}$ & 0.05 \\
Negative & $24(45.3 \%)$ & 0.05 \\
\hline $\begin{array}{l}\text { Number of vomiting } \\
\text { 3 times/day }\end{array}$ & $30(56.6 \%)$ & $2(28.6 \%)$ & 0.05 \\
$<3$ times/day & $23(43.4 \%)$ & $5(71.4 \%)$ & 0.05 \\
\hline
\end{tabular}

Table 5: Comparison between the 2 Types of Treatment Regime in the Seropositive H.Pyloriin HG Pregnant Women

\begin{tabular}{|l|c|c|c|}
\hline \multicolumn{1}{|c|}{ Criteria } & $\begin{array}{c}\text { Traditional Regime } \\
\text { Group } \\
\text { N=17 }\end{array}$ & $\begin{array}{c}\text { H.Pyloriregime } \\
\text { Group } \\
\text { N=17 }\end{array}$ & P Value \\
\hline Days of hospitalization more than 3 days. & $16(94 \%)$ & $5(29.4 \%)$ & 0.01 \\
\hline Persistence of ketonuria. & $14(82.6 \%)$ & $5(29.5 \%)$ & 0.01 \\
\hline Number of vomiting attacks/day. & $7(41.2 \%)$ & $\begin{array}{c}12(70.6 \%) \\
5(29.4 \%)\end{array}$ & $>0.07$ \\
Decrease vomiting attack <3/day. & $10(58.8 \%)$ & 0.05 \\
Attack of >3/day. & & & \\
\hline
\end{tabular}




\section{DISCUSSIONS}

Helicobacter pylori is one of the commonest bacterial infection worldwide and accepted as a cause of chronic active gastritis, most patients continue through life with chronic superficial gastritis while others develop either duodenal or gastric ulcer ${ }^{(7)}$. The present study revealed higher H.pyloriseropositivity in pregnant women with HG. However, the prevalence rate for this organism is higher in developing countries than developed countries (Soll, 1996). The overall prevalence of seropositivitywas $65-91 \%$ in pregnant women with $\mathrm{HG}^{(8,9)}$.

The high rate of H.pyloriin pregnant women during the early pregnancy due to increased accumulation of fluid and the displacement of intracellular and extracellular volume caused by the increase in the steroid hormone result in a change of $\mathrm{pH}$ in gastrointestinal tract ${ }^{(10)}$. In addition, the altered humoral and cell mediated immunity also contribute to the manifestation of a latent H.pyloriinfection ${ }^{(11)}$.

The present study indicates that the gastrointestinal symptoms during pregnancy were more common in young educated primigravida (25 years of age) which is in contrast to other study who agreed with occurrence of HG in young primigravida but less educated ${ }^{(12)}$.

The results of this study could not demonstrate any correlation between the onset and duration of symptoms and seropositivity in HG group. These findings may reflect either the existence of underlying mechanism other than HG in the exacerbation of HG or the complex nature of the H.pyloriinfection related symptoms. It has been suggested that oral antibiotics give a good treatment response for H.pyloriin $\mathrm{HG}^{(13)}$. Thus, in relation to days of hospitalization, persistence ketonuria and vomiting attack, H.pyloritreatment regime is recommended.

In conclusion, H.pylorishould be considered as one of the causes of HG. Also non teratogenic regimen for treatment of H.pylorimay be considered in intractable cases.

\section{REFERENCES}

1. Fairweather DV. Nausea and vomiting in pregnancy. Am J ObstetGynecol 1968; 102: 135-175.

2. Gadsby R, Barnie-AdsheadAM, Jagger CA. A prospective study of nausea and vomiting during pregnancy. Br J Gen Pract 1993; 43: 245-248.

3. Gar-Allah SZ. The Role of Helicobacter pylori in Pathogenesis of Hyperemesis Gravidarum. M.Sc. Thesis, University of Basrah, Iraq 2016.

4. Graham DY, Yamaoka Y. Disease-specific Helicobacter pylori virulence factors: the unfulfilled promise. Helicobacter $2000 ; 5$ Suppl 1: S3-9; discussion S27-31 (PMID: 10828748).

5. Yamaoka Y, Kwon DH, Graham DY. Proinflammatory outer membrane protein (oipA) of Helicobacter pylori ProcNatlAcadSci USA 2000; 97: 7533-7538 (PMID: 10852959 DOI: 10.1073/pans. 130079797).

6. Mahdvi J, Sonden B, Hurtig M et al. Helicobacter pylori sab A adhesion in persistent infection and chronic inflammation. Science 2002; 297: 573-578 (PMID: 12142529 DOI: 10.1126/Science. 1069076).

7. Soll AH. Helicobacter pylori induced gastritis in: Bennet JO, Plum E (eds). Cecil Texbook of Medicine, $20^{\text {th }}$ ed, Philadelphia: W B Saunders, 1996: 659-660.

8. Mulchandani, Rupa, et al. "Helicobacter SPP. Detected in Liver, Pancreas in Human Patients with Tumours." 
9. Verberg MT, Gillot DJ, Al-Fardan N, Grudzinskor JG. Hyperemesis gravidarum, a literature review. Hum Reprod Update 2005; 11: 527-539.

10. Berker B, Soylemez F, Cengiz SD, Kosesk S. Serologic assay of Helicobacter pylori infection. Is it useful in hyperemesis gravidarum? J Reprod Med 2003; 48: 809-812 (Pub Med).

11. Frigo P, Lang C, Resenberger K, Koibi H. Hyperemesis gravidarum associated with Helicobacter pylori seropositivity. ObstetGynecol 1998; 91(4): 615-617.

12. Wugy T, Seng J, Ghon MM. Correlation between Helicobacter pylori infection and gastrointestinal symptoms in pregnancy. Adu Therapy 2000; 17(3): 152-158.

13. Mustafa, Murtaza., et al. "Brain abscess: pathogenesis, diagnosis and management strategies." Int J Res Applied, Natural Soc Sci 2 (2014): 299-308.

14. Kocak I, Akany A, Ustun C et al. Helicobacter pylori seropositivity in patients with hyperemesis gravidarum. Int J GynecolObstet 1999; 66(3): 251-254.

15. Jacoby EB, Ponter KB. Helicobacter pylori infection and persistent hyperemesis gravidarum. Am J Perinatol 1999; 16(2): 8588 . 
